\title{
Efficiency of Currency Derivatives in Price Discovery Process: Evidences from India
}

\author{
Prashant Sharma*, Varun Chotia* \\ Jaipuria Institute of Management, Jaipur, India \\ Email: *prashant.sharma@jai puria.ac.in, *va run.chotia@jaipuria.ac.in
}

How to cite this paper: Sharma, P. and Chotia, V. (2019) Efficiency of Currency Derivatives in Price Discovery Process: Evidences from India. Theoretical Economics Letters, 9, 1669-1681. https://doi.org/10.4236/tel.2019.95106

Received: May 10, 2019

Accepted: June 24, 2019

Published: June 27, 2019

Copyright $\odot 2019$ by author(s) and Scientific Research Publishing Inc. This work is licensed under the Creative Commons Attribution International License (CC BY 4.0).

http://creativecommons.org/licenses/by/4.0/

(c) (i) Open Access

\begin{abstract}
The present study investigates the efficiency of currency derivatives market by assessing its contribution towards price discovery process using spot and future prices of four currencies (USD/INR, EURO/INR, GBP/INR and $J P Y I I N R$ ) traded on the National Stock Exchange (NSE), India. As per the investigation, it can be concluded that there is a long run equilibrium relationship between spot rates and future rates, with unidirectional causality running from future rates to spot rates for all currencies under consideration. As the futures markets contribute more to the price discovery, this implies that more investors are attracted to it. This in turn leads to more rational price discovery.
\end{abstract}

\section{Keywords}

Price Discovery, Short Run Causality, Long Run Causality, Vector Error Correction Model (VECM)

\section{Introduction}

Price discovery refers to the process of determining the price of a traded asset or an instrument in a market. As for other commodities, the price is determined by the interaction of the demand and supply forces. Due to the increase in the popularity of the futures market, there is much more activity than before. Thus, there is an increase in the information floating around. In an efficient market, as the information is freely available to all the participants, there is push and pull resulting from the demand and supply forces. But, as it is widely agreed that the markets are far from efficient, studying the lead and lag relationship between major market components is of vital importance. Foreign exchange (FX) or the currency markets play a major role in integrating economies all over the world. 
The market participants include retail investors, brokers, multi-national corporations, public and private banks, central banks, hedge funds, etc.

The forex market in India has come a long way in terms of the number of participants, overall market turnover and variety of instruments. Today, Indian forex market is an attractive destination for investors and has seen an increase in the turnover for different foreign currencies. Over the years, the increase in the number of participants and the thriving derivative products for trading and hedging risk have added to the depth and complexity of the market. Due to this increase in the number of the participants and the changing structure of the market, there is a need of increased transparency, stability, and efficiency. This is one of the reasons currency futures were introduced.

In line with the above thought, RBI has been trying to adjust many policies and formulate new ones to make the forex markets more efficient. For that purpose, one needs to better comprehend how the market and the various components in it behave. One of the ways of that is to understand the price discovery process in the spot and futures market.

Furthermore, currently with the development of the forex markets, especially the futures market, most of the research has been done on the lead-lag relationship and the efficiency of currency derivatives in determining the price discovery process in the developed countries. There is dearth of such studies on the developing economies. Also, the major focus of previous studies have been on assessing the efficiency of futures in determining the price discovery process and lead-lag relationship in the stock markets, commodities market and not many efforts have been made in the context of currency derivatives.

The current study talks about the lead-lag relationship between spot and futures prices in the context of Indian forex markets. This information can be used to device a trading strategy so as to earn more returns as compared to the passive buy and hold strategy. This way the results of the price discovery examination can be used not only by the regulators but will also be beneficial to the market participants.

In terms of the limitations of the paper, the study can be expanded to other currencies and nations in order to expand the horizon of price discovery process. Other empirical techniques can be applied in order to carry out the analysis so as to if the final results come out in the same way or not.

Section 2 summarizes the important literature on this topic. Data and methodology relevant to this study are discussed in Section 3. The results of the empirical analysis are illustrated and reported in Section 4 . The conclusions of the study are given in Section 5. Finally, the future scope of this study is discussed in Section 6.

\section{Literature Review}

Price discovery is a key function of the financial markets [1]. In an efficient market, the effect of all the information available to the market participants is 
incorporated into the price of the financial assets. In accordance with the efficient market hypothesis proposed by [2] and further discussed by various academic studies [3] [4] [5], all the available information should be fully reflected in the asset prices. The purpose of price discovery analysis is to investigate as to which market is providing most useful information for determining the fundamental value of the asset. Unfortunately, so far, the concept of price discovery in the financial markets has not been completely grasped.

To know if the spot or the futures market is dominant in the respect of price discovery and which one of them takes the lead is of vital importance to the market participants as well as the regulators. Due to this, the quantification of the process of price discovery has gained importance in the area of empirical finance. Most widely held view is that the process of price discovery is dominated by the futures markets, across different assets [6] [7]. This is majorly because of the lower transaction costs. The process of price discovery has been widely studied under a number of settings, particularly the price discovery of stocks listed on different exchanges. The role of price discovery and volatility spill-over in informationally linked futures market has been studied extensively. Most of the researches on price discovery and the possible volatility consequences for the spot market are focused on a few developed countries, especially the USA. [8] and [9] have studied the price discovery of the stocks in the USA which are traded on different exchanges, with reference to the relative contributions of the NYSE and the regional exchanges. After analysing the commodity spot markets and futures markets, [10] has stated that about 75 percent of the new information first gets incorporated in the future prices. Articles describing the links between stock markets and stock index futures markets include [11]-[16]. Researchers have also studied other equity derivative products. The links between stock markets and option markets have been studied by [17]-[23].

Some other important studies which focus on the price discovery and volatility spill-overs in commodity and stock market's index futures are [24] [25] and [26]. The price discovery mechanism in India's National Stock Exchange (NSE) spot market and future market was studied by [27]. The study uses Johansen's cointegration test and Vector Error Correction Mechanism (VECM) to empirically conclude that there is a bilateral causality between S\&P CNX Nifty index and the index futures, for the period from June 2002 to February 2005. Only few researches have tried to examine the price discovery process in the forex market, especially the forex futures market. [28] [29] [30] [31] [32] are some of the major studies that have analysed the foreign exchange markets in mature and emerging economies. [33] has studied the price discovery process in the currency markets by incorporating new information into the exchange rate dynamics. For the European markets, [34] has studied the impact of macroeconomic news and central bank announcements on the exchange rates. [35] has tried to study as to which market (spot market or future market) has greater contribution to price discovery. These studies conclude that in comparison to the spot market, the futures market have greater contribution to price discovery in the currency markets. 
One major shortcoming of the existing studies on price discovery is that most of the studies focus on measuring price discovery over a relatively short period of time, typically less than a year. As such, variations in price discovery over time have not really been examined in the literature. Additionally, the process of price discovery and volatility spill-over has been studied majorly for the equity and commodity markets in the USA and other developed countries [36] [37] [38] [39]. Not much attention has been given to foreign exchange markets in the emerging countries. However, because of the increasing activity in the currency markets of emerging countries, it is of strong interest to see whether the new information is fully and immediately incorporated in prices of traded currencies or not. As far as the examination of price discovery is concerned, the published evidence on Indian economy is very scarce. There is hardly any study on India's foreign exchange market that has investigated the price discovery, majorly because of the recent origin and smaller size of the market. The present study is an attempt to fill this research gap.

\section{Data and Methodology}

Daily time series data for EURO/INR, GBPIINR and JPYIINR spot and future exchange rates from 1st January 2015 to 12th March 2019 (except for USD/INR where data was considered for period of 1st January 2015 to 28th November 2018) was used for this study. The data has been sourced from the databases of National Stock Exchange of India Ltd. (NSE) and Reserve Bank of India (RBI).

Before proceeding for the analysis, the descriptive statistics for all the variables are mentioned below (Table 1).

\section{a) Testing for stationarity and co-integration of variables}

Prior to the analysis, the Augmented Dickey-Fuller test (ADF) was employed to check for the stationarity of the spot and future exchange rates for all currencies [40]. The ADF tests were performed on both the level and first differenced observations and to determine the degree of integration of the data series. This was done to check for the possibility of spurious relationships between spot and future prices.

Consequently, in the case of non-stationarity, the maximum likelihood approach of [41] is used to investigate the presence of long-term equilibrium relationship between the spot and future prices. This test reports the maximal eigen-value and the trace statistic tests for each of the variable. The null hypothesis states that there is no co-integrated relationship between the variables. Presence of a co-integrated relationship between two variables is an evidence of the long-run equilibrium relationship between them. This also implies that there is a linear combination of the two variables that is stationary. As the test results are sensitive to the number of lags chosen, information criteria have been chosen to select the best lag length.

\section{b) Causality analysis}

Granger causality test has been undertaken to test for the possibility of causality relationships between the spot exchange rates and the future exchange rates 
Table 1. Descriptive statistics.

(a)

\begin{tabular}{ccccc}
\hline & USD_INR_FUT & USD_INR_SPOT & EURO_INR_FUT & EURO_INR_SPOT \\
\hline Mean & 66.28658 & 66.14007 & 75.39605 & 75.21103 \\
Median & 66.5275 & 66.3495 & 75.05 & 74.8987 \\
Maximum & 74.5025 & 74.3875 & 86.0025 & 85.9012 \\
Minimum & 61.3975 & 61.4105 & 66.035 & 65.9451 \\
Std. Dev. & 2.503906 & 2.517663 & 4.172498 & 4.168791 \\
Skewness & 0.835786 & 0.841964 & 0.319533 & 0.313544 \\
Kurtosis & 3.995152 & 4.027828 & 2.441432 & 2.446805 \\
Jarque-Bera & 142.3911 & 146.4381 & 30.28693 & 29.39821 \\
Probability & 0.000 & 0.000 & 0.000 & 0.000 \\
Sum & 59856.78 & 59724.48 & 76074.61 & 75887.93 \\
Sum Sq. Dev. & 5655.132 & 5717.442 & 17549.02 & 17517.85 \\
\hline
\end{tabular}

(b)

\begin{tabular}{ccccc}
\hline & GBP_INR_FUT & GBP_INR_SPOT & JYP_INR_FUT & JYP_INR_SPOT \\
\hline Mean & 91.32356 & 91.11695 & 59.12248 & 58.98463 \\
Median & 90.9425 & 90.6625 & 58.94625 & 58.775 \\
Maximum & 104.8425 & 105.1 & 67.165 & 67.15 \\
Minimum & 80.0875 & 79.8563 & 51.185 & 51.06 \\
Std. Dev. & 6.078118 & 6.064364 & 4.272261 & 4.275719 \\
Skewness & 0.07663 & 0.077437 & -0.140086 & -0.143368 \\
Kurtosis & 1.870926 & 1.877638 & 2.042168 & 2.046494 \\
Jarque-Bera & 54.58254 & 53.96819 & 41.91238 & 41.72105 \\
Probability & 0.000 & 0.000 & 0.000 & 0.000 \\
Sum & 92145.47 & 91,937 & 59713.7 & 59574.48 \\
Sum Sq. Dev. & 37239.07 & 37070.72 & 18416.48 & 18446.31 \\
\hline
\end{tabular}

for the different currencies under consideration. In this way, it is possible to examine both the long run causality captured by the significance of the error-correction term and the short run causality derived by testing the significance of sum of the lags of explanatory variables. For the currency pair USD/INR, the spot rate and exchange rate can be written in the following Vector Error Correction ( $V E C$ ) form:

$$
\begin{aligned}
& \Delta\left(\frac{U S D}{I N R} \text { Spot }\right)_{t} \\
& =\alpha_{1}+\beta_{1} \sum_{i=1}^{i=p} \Delta\left(\frac{U S D}{I N R} \text { Spot }\right)_{t-i}+\gamma_{1} \sum_{i=1}^{i=q} \Delta\left(\frac{U S D}{I N R} \text { Future }\right)_{t-i}+\lambda_{1} e_{t-1}+v_{1 t}
\end{aligned}
$$




$$
\begin{aligned}
& \Delta\left(\frac{U S D}{I N R} \text { Future }\right)_{t} \\
& =\alpha_{2}+\beta_{2} \sum_{i=1}^{i=p} \Delta\left(\frac{U S D}{I N R} \text { Spot }\right)_{t-i}+\gamma_{2} \sum_{i=1}^{i=q} \Delta\left(\frac{U S D}{I N R} \text { Future }\right)_{t-i}+\delta_{1} e_{t-1}+u_{1 t} \\
& \Delta\left(\frac{E U R O}{I N R} \text { Spot }\right)_{t} \\
& =\alpha_{3}+\beta_{3} \sum_{i=1}^{i=p} \Delta\left(\frac{E U R O}{I N R} \text { Spot }\right)_{t-i}+\gamma_{3} \sum_{i=1}^{i=q} \Delta\left(\frac{E U R O}{I N R} \text { Future }\right)_{t-i}+\lambda_{2} e_{t-1}+v_{2 t} \\
& \Delta\left(\frac{E U R O}{I N R} \text { Future }\right)_{t} \\
& =\alpha_{4}+\beta_{4} \sum_{i=1}^{i=p} \Delta\left(\frac{E U R O}{I N R} \text { Spot }\right)_{t-i}+\gamma_{4} \sum_{i=1}^{i=q} \Delta\left(\frac{E U R O}{I N R} \text { Future }\right)_{t-i}+\delta_{2} e_{t-1}+u_{2 t} \\
& \Delta\left(\frac{G B P}{I N R} \text { Spot }\right)_{t} \\
& =\alpha_{5}+\beta_{5} \sum_{i=1}^{i=p} \Delta\left(\frac{G B P}{I N R} \text { Spot }\right)_{t-i}+\gamma_{5} \sum_{i=1}^{i=q} \Delta\left(\frac{G B P}{I N R} \text { Future }\right)_{t-i}+\lambda_{3} e_{t-1}+v_{3 t} \\
& \Delta\left(\frac{G B P}{I N R} \text { Future }\right)_{t} \\
& =\alpha_{6}+\beta_{6} \sum_{i=1}^{i=p} \Delta\left(\frac{G B P}{I N R} \text { Spot }\right)_{t-i}+\gamma_{6} \sum_{i=1}^{i=q} \Delta\left(\frac{G B P}{I N R} \text { Future }\right)_{t-i}+\delta_{3} e_{t-1}+u_{3 t} \\
& \Delta\left(\frac{J P Y}{I N R} \text { Spot }\right)_{t} \\
& =\alpha_{7}+\beta_{7} \sum_{i=1}^{i=p} \Delta\left(\frac{J P Y}{I N R} \text { Spot }\right)_{t-i}+\gamma_{7} \sum_{i=1}^{i=q} \Delta\left(\frac{J P Y}{I N R} \text { Future }\right)_{t-i}+\lambda_{4} e_{t-1}+v_{4 t} \\
& \Delta\left(\frac{J P Y}{I N R} \text { Future }\right)_{t} \\
& =\alpha_{8}+\beta_{8} \sum_{i=1}^{i=p} \Delta\left(\frac{J P Y}{I N R} \text { Spot }\right)_{t-i}+\gamma_{8} \sum_{i=1}^{i=q} \Delta\left(\frac{J P Y}{I N R} \text { Future }\right)_{t-i}+\delta_{4} e_{t-1}+u_{4 t}
\end{aligned}
$$

where $\Delta$, as usual is the first difference operator and $e_{t-1}$ is the lagged residual term from the co-integrating regression, which is nothing but the error correction term. The above equations are used to evaluate the causality between changes in spot rates and future rates. In Equations (1), (3), (5) and (7), existence of a causal relationship running from change in future prices to spot prices is evaluated. In Equations (2), (4), (6) and (8), existence of a causal relationship running from change in spot prices to future prices is evaluated.

If the dependent variables can be driven by the error term obtained in the co-integrating equation, this implies that there exists a long-run causal relationship between the dependent and independent variables. This can be done by testing $H_{0}: \lambda=0$ (or $H_{0}: \delta=0$ ). If the error correction terms are non-significant, this implies that the dependent variable responds only to the short-term shocks. Similarly, short-term causality is confirmed by the rejection of the non-significance of the difference explanatory variables by the Wald test. 


\section{Empirical Results and Discussion}

Co-integration analysis necessitates that the variables under consideration be integrated of the same order. Hence, it is necessary to undertake unit-root tests before co-integration analysis. Table 2 reports the results for ADF test (only constant).

It can be seen that for all currency pairs at level, the null hypothesis of nonstationarity cannot be rejected at $10 \%$ level of significance (for both spot rates and future rates). However, when first differences are taken, the null hypothesis of non-stationarity is rejected for spot rates and future rates of all the currency pairs. In other words, these variables are integrated of order 1 . This satisfies the necessary condition for co-integration to exist.

The next step is to test for the presence of long-term (co-integrating) relationship between spot rates and future rates. The results of Johansen co-integration test are summarised in Table 3 and Table 4, which report the maximal eigen-value and the trace statistic tests for spot rates and future rates for each of the currency pairs (For co-integration analysis, Hannan-Quinn information criteria suggests an optimal lag-length of 2 for all the currency pairs under consideration).

The null hypothesis states that there is no co-integrating relationship between the spot rate and the future rate. The above results reveal that both the trace statistics and max-eigen statistics reject the null hypothesis of zero co-integrating vectors in favour of one co-integrating vector for all the currency pairs at the $5 \%$ level of significance. The existence of co-integration relationships among the spot rates and future rates suggests that there must be causality in at least one direction.

To determine the direction of causality, along with being able to distinguish between short-run and long-run causality, Vector Error Correction Model (VECM) is deployed. Table 5 provides the joint Wald F-statistics of the lagged explanatory variables. These tests provide an evidence for or against the significance

Table 2. Augmented dickey fuller test (ADF) unit root test.

\begin{tabular}{|c|c|c|c|c|c|}
\hline $\begin{array}{c}\text { Exchange } \\
\text { Rate }\end{array}$ & Variables & t-Statistics at Level & p-Value & $\begin{array}{c}\text { t-Statistics at First } \\
\text { Difference }\end{array}$ & $\mathrm{p}$-Value \\
\hline \multirow{2}{*}{$U S D / I N R$} & $U S D / I N R$ Spot & -0.967602 & 0.7663 & $-31.77097^{\star}$ & 0.0000 \\
\hline & $U S D / I N R$ Futures & -1.044505 & 0.7389 & $-23.16401^{\star}$ & 0.0000 \\
\hline \multirow{2}{*}{ EUROIINR } & EUROIINR Spot & -1.572539 & 0.4963 & $-30.75897^{\star}$ & 0.0000 \\
\hline & EUROIINR Futures & -1.552560 & 0.5066 & $-31.08740^{*}$ & 0.0000 \\
\hline \multirow{2}{*}{$G B P / I N R$} & $G B P / I N R$ Spot & -1.757290 & 0.4020 & $-29.99626^{\star}$ & 0.0000 \\
\hline & $G B P / I N R$ Futures & -1.826735 & 0.3676 & $-29.78690^{\star}$ & 0.0000 \\
\hline \multirow{2}{*}{$J P Y I I N R$} & $J P Y I I N R$ Spot & -1.697988 & 0.4320 & $-32.43747^{\star}$ & 0.0000 \\
\hline & $J P Y I I N R$ Futures & -1.628750 & 0.4674 & $-32.72482^{*}$ & 0.0000 \\
\hline
\end{tabular}

* indicates statistical significance at $5 \%$ significance level. 
Table 3. Johansen cointegration test results (Trace statistics).

\begin{tabular}{|c|c|c|c|c|c|c|}
\hline Variables & $\begin{array}{c}\text { Number } \\
\text { of Lags }\end{array}$ & $\begin{array}{l}\text { Hypothesized } \\
\text { No. of } \mathrm{CE}(\mathrm{s})\end{array}$ & Eigenvalue & $\begin{array}{c}\text { Trace } \\
\text { Statistic }\end{array}$ & $\begin{array}{l}0.05 \text { Critical } \\
\text { Value }\end{array}$ & Prob. \\
\hline USD/INR Spot & \multirow{2}{*}{2} & None* & 0.129246 & 125.2173 & $15.49471^{\star}$ & 0.0001 \\
\hline USD/ INR Futures & & At most 1 & 0.000734 & 0.661070 & 3.841466 & 0.4162 \\
\hline $\begin{array}{c}E U R O / I N R \text { Spot } \\
\text { EUROIINR }\end{array}$ & \multirow{2}{*}{2} & None ${ }^{*}$ & 0.214378 & 245.1713 & $15.49471^{\star}$ & 0.0001 \\
\hline Futures & & At most 1 & 0.002426 & 2.443928 & 3.841466 & 0.1180 \\
\hline GBP/INR Spot & \multirow{2}{*}{2} & None ${ }^{*}$ & 0.226558 & 261.4933 & $15.49471^{\star}$ & 0.0001 \\
\hline$G B P / I N R$ Futures & & At most 1 & 0.003024 & 3.046968 & 3.841466 & 0.0809 \\
\hline$J P Y \mid I N R$ Spot & \multirow{2}{*}{2} & None $^{*}$ & 0.232314 & 268.8235 & $15.49471^{\star}$ & 0.0001 \\
\hline$J P Y I I N R$ Futures & & At most 1 & 0.002577 & 2.598811 & 3.841466 & 0.1069 \\
\hline
\end{tabular}

* indicates statistical significance at $5 \%$ significance level.

Table 4. Johansen cointegration test results (Max-Eigen statistics).

\begin{tabular}{|c|c|c|c|c|c|c|}
\hline Variables & $\begin{array}{c}\text { Number } \\
\text { of Lags }\end{array}$ & $\begin{array}{l}\text { Hypothesized } \\
\text { No. of } \mathrm{CE}(\mathrm{s})\end{array}$ & Eigenvalue & $\begin{array}{l}\text { Max-Eigen } \\
\text { Statistics }\end{array}$ & $\begin{array}{l}0.05 \text { Critical } \\
\text { Value }\end{array}$ & Prob. \\
\hline USD/INR Spot & \multirow{2}{*}{2} & None $^{*}$ & 0.129246 & 124.5562 & $14.26460^{*}$ & 0.0001 \\
\hline$U S D / I N R$ Futures & & At most 1 & 0.000734 & 0.661070 & 3.841466 & 0.4162 \\
\hline EUROI INR Spot & \multirow[b]{2}{*}{8} & None* & 0.214378 & 242.7274 & $14.26460^{*}$ & 0.0001 \\
\hline $\begin{array}{c}\text { EURO/INR } \\
\text { Futures }\end{array}$ & & At most 1 & 0.002426 & 2.443928 & 3.841466 & 0.1180 \\
\hline$G B P / I N R$ Spot & \multirow{2}{*}{2} & None $^{*}$ & 0.226558 & 258.4464 & $14.26460^{\star}$ & 0.0001 \\
\hline GBPIINR Futures & & At most 1 & 0.003024 & 3.046968 & 3.841466 & 0.0809 \\
\hline$J P Y I I N R$ Spot & & None $^{*}$ & 0.232314 & 266.2247 & $14.26460^{*}$ & 0.0001 \\
\hline$J P Y I I N R$ Futures & & At most 1 & 0.002577 & 2.598811 & 3.841466 & 0.1069 \\
\hline
\end{tabular}

${ }^{*}$ indicates statistical significance at $5 \%$ significance level.

of the short-run causal effects. Finally, Table 6 provides the t-statistics for the coefficients of the error correction terms, which give an indication of long-run causal effects.

Results in Table 5 imply that in the short run, there is causality running from the future rates to the spot rates for all currency pairs except JPYIINR. F-test statistic is not significant for $J P Y I I N R$ at $5 \%$ level of significance.

Table 6 shows that all the error correction terms (those capturing causality relationship from the future rates to the spot rates) are negative and have t-statistics which are significant at $5 \%$ level of significance. This establishes the unidirectional causality, running from the future rates to the spot rates, in the long run for all the currency pairs. The error correction term depicts the speed of correction of the short-term rates towards the long-term steady. Adjustment in spot rates is maximum for $J P Y I I N R$ at a speed of convergence to equilibrium of $82.5 \%$. The negative values of the error correction terms confirm the stability of the system. Also, the speed of adjustment for all the currency pairs is fairly rapid. 
Table 5. Wald test (Testing for short run causality from future rates to spot rates).

\begin{tabular}{|c|c|c|c|}
\hline Variables & Chi-square Statistics & Df & Prob. \\
\hline $\begin{array}{c}\text { USD/INR Spot } \\
\text { USD/ INR Futures }\end{array}$ & $76.36413^{*}$ & 2 & 0.0000 \\
\hline $\begin{array}{c}\text { EURO/INR Spot } \\
\text { EURO/INR Futures }\end{array}$ & $10.17732^{*}$ & 2 & 0.0062 \\
\hline $\begin{array}{c}G B P / I N R \text { Spot } \\
G B P / I N R \text { Futures }\end{array}$ & $16.22894^{*}$ & 2 & 0.0003 \\
\hline $\begin{array}{c}J P Y \mid I N R \text { Spot } \\
J P Y \mid I N R \text { Futures }\end{array}$ & 4.404702 & 2 & 0.1105 \\
\hline
\end{tabular}

* indicates statistical significance at $5 \%$ significance level.

Table 6. Vector error correction model.

\begin{tabular}{|c|c|c|c|c|c|c|c|c|}
\hline $\begin{array}{c}\text { Error } \\
\text { Correction }\end{array}$ & $\begin{array}{c}\mathrm{D}(\text { (USD/INR } \\
\text { Spot) }\end{array}$ & $\begin{array}{c}\mathrm{D}(U S D / I N R \\
\text { Futures })\end{array}$ & $\begin{array}{l}\mathrm{D} \text { (EUROI } \\
\text { INR Spot) }\end{array}$ & $\begin{array}{l}\mathrm{D} \text { (EURO/INR } \\
\text { Futures) }\end{array}$ & $\begin{array}{c}\mathrm{D}(G B P / I N R \\
\text { Spot })\end{array}$ & $\begin{array}{c}\mathrm{D}(G B P / I N R \\
\text { Futures })\end{array}$ & $\begin{array}{l}\mathrm{D}(J P Y \mid I N R \\
\text { Spot })\end{array}$ & $\begin{array}{c}\mathrm{D}(J P Y \mid I N R \\
\text { Futures })\end{array}$ \\
\hline \multirow{3}{*}{ CointEq1 } & $-0.290589^{*}$ & $0.148606^{*}$ & $-0.642371^{\star}$ & 0.096129 & $-0.579403^{*}$ & 0.275555 & $-0.825269^{*}$ & 0.002819 \\
\hline & $(0.05359)$ & $(0.06371)$ & $(0.07374)$ & $(0.08277)$ & $(0.08078)$ & $(0.09384)$ & $(0.08710)$ & $(0.09581)$ \\
\hline & {$[-5.42263]$} & [2.33250] & {$[-8.71111]$} & [1.16135] & [-7.17249] & [2.93642] & {$[-9.47521]$} & [0.02942] \\
\hline \multirow{3}{*}{$S(-1)$} & -0.361254 & -0.127987 & -0.072148 & -0.017299 & -0.099637 & -0.016877 & 0.033724 & 0.095605 \\
\hline & $(0.05836)$ & $(0.06938)$ & $(0.06564)$ & $(0.07368)$ & $(0.06959)$ & $(0.08084)$ & $(0.07359)$ & $(0.08095)$ \\
\hline & {$[-6.19018]$} & {$[-1.84464]$} & {$[-1.09912]$} & {$[-0.23478]$} & {$[-1.43171]$} & {$[-0.20877]$} & [0.45827] & [1.18101] \\
\hline \multirow{3}{*}{$S(-2)$} & -0.010929 & -0.048062 & 0.014924 & -0.024496 & 0.020063 & -0.031174 & 0.085104 & 0.082734 \\
\hline & $(0.04569)$ & $(0.05432)$ & $(0.04777)$ & $(0.05362)$ & $(0.04810)$ & $(0.05588)$ & $(0.05218)$ & $(0.05740)$ \\
\hline & {$[-0.23923]$} & {$[-0.88488]$} & {$[0.31241]$} & {$[-0.45681]$} & [0.41707] & {$[-0.55786]$} & [1.63098] & [1.44139] \\
\hline \multirow{3}{*}{$\mathrm{F}(-1)$} & 0.424256 & 0.121190 & 0.173161 & 0.056501 & 0.224721 & 0.150833 & 0.001107 & -0.102822 \\
\hline & $(0.05622)$ & $(0.06684)$ & $(0.06849)$ & $(0.07688)$ & $(0.07087)$ & $(0.08233)$ & $(0.07734)$ & $(0.08508)$ \\
\hline & [7.54674] & [1.81323] & [2.52828] & [0.73494] & [3.17077] & [1.83205] & [0.01431] & {$[-1.20853]$} \\
\hline \multirow{3}{*}{$F(-2)$} & 0.021333 & -0.012403 & 0.001572 & 0.031705 & 0.010383 & 0.009428 & -0.092148 & -0.126963 \\
\hline & $(0.05014)$ & $(0.05962)$ & $(0.05427)$ & $(0.06092)$ & $(0.05397)$ & $(0.06269)$ & $(0.05840)$ & $(0.06424)$ \\
\hline & [0.42544] & {$[-0.20805]$} & {$[0.02896]$} & [0.52044] & [0.19239] & [0.15037] & {$[-1.57786]$} & {$[-1.97630]$} \\
\hline \multirow{3}{*}{$\mathrm{C}$} & 0.007713 & 0.008361 & 0.002404 & 0.002785 & -0.005088 & -0.005326 & 0.009547 & 0.010323 \\
\hline & $(0.00656)$ & $(0.00780)$ & $(0.01198)$ & $(0.01345)$ & $(0.01588)$ & $(0.01844)$ & $(0.01119)$ & $(0.01231)$ \\
\hline & [1.17564] & [1.07195] & {$[0.20069]$} & {$[0.20706]$} & {$[-0.32051]$} & {$[-0.28880]$} & [0.85335] & [0.83879] \\
\hline
\end{tabular}

* indicates statistical significance at $5 \%$ significance level.

The analysis came out to be robust as the model had no Multicollinearity and was also checked for autocorrelation using the Durbin Watson statistic and heteroskedasticity using Breusch-Pagan/Cook-Weisberg test. The test statistic value of Durbin Watson is 1.25. The Breusch-Pagan test for heteroskedasticity with a null hypothesis of constant variance is 0.90 . Through this test, we fail to reject the null hypothesis which ultimately confirms constant variance or homoscedasticity. 


\section{Conclusions}

To understand the nuances of the market and its components, one needs to understand the price discovery process. The relationship of the currency futures and spot market for the four currencies-USD, GBP, EURO and JPY is analysed. As per the above results there is a long run equilibrium relationship between the futures and spot markets for all the four currencies considered. This study concludes that the spot market follows the futures market so as to attain the equilibrium in the long run. As the price is first reflected in the futures market, arbitragers and speculators take advantage of this mismatch. This moves the spot market price towards the equilibrium. Futures market being more efficient in incorporating new information, plays a major role in price discovery. This goes to show that the Indian forex market suffers from informational efficiency.

Even when the trading volume is higher in the foreign exchange spot market, the futures market has an important role to pay in price discovery. This is supported by the fact that there is much higher level of transparency in the future market as compared to direct interdealer spot trading. The future prices lead the spot price due to the assimilation of the new information in the short-run. Also, the cash market for the currencies under consideration is very well developed. [42] states that in the case of lower transaction costs and faster trade execution, secondary markets can play an important part in the price discovery process.

This information can be used by regulators like RBI and SEBI to lay down better policies for the growth of the markets. As the futures markets lead price discovery, this goes to say that the participants are more attracted towards the futures market. Thus, it is crucial for the regulators to maintain better inspection and control over the spot markets as well. Because the investors are more attracted to a fair, transparent and efficient market, this leads to greater number of participants in the futures market. Greater number of market participant ensures a more reasonable and democratic price discovery.

\section{Future Scope of Study}

The present findings of this paper on the price discovery process can be complemented by examining the volatility spill-overs between spot and futures market. This may help one to understand completely the asymmetric reactions in the forex market. This will help policy makers, portfolio managers, traders and other market participants to identify the source of volatility and to take corrective measures.

\section{Conflicts of Interest}

The authors declare no conflicts of interest regarding the publication of this paper.

\section{References}

[1] Eun, C.S. and Sabherwal, S. (2003) Cross-Border Listings and Price Discovery: Evi- 
dence from US-Listed Canadian Stocks. The Journal of Finance, 58, 549-575. https://doi.org/10.1111/1540-6261.00537

[2] Fama, E.F. (1991) Efficient Capital Markets: II. The Journal of Finance, 46, 1575-1617. https://doi.org/10.1111/j.1540-6261.1991.tb04636.x

[3] Grossman, S.J. and Stiglitz, J.E. (1980) On the Impossibility of Informationally Efficient Markets. The American Economic Review, 70, 393-408.

[4] Thaler, R. and De Bondt, W.F.M. (1985) Does the Stock Market Overreact? The Journal of Finance, 40, 793-805.

[5] Lo, A.W. and MacKinlay, A.C. (1988) Stock Market Prices Do Not Follow Random Walks: Evidence from a Simple Specification Test. The Review of Financial Studies, 1, 41-66. https://doi.org/10.1093/rfs/1.1.41

[6] So, R.W. and Tse, Y. (2004) Price Discovery in the Hang Seng Index Markets: Index, Futures, and the Tracker Fund. Journal of Futures Markets. Futures, Options, and Other Derivative Products, 24, 887-907. https://doi.org/10.1002/fut.20112

[7] Theissen, E. (2012) Price Discovery in Spot and Futures Markets: A Reconsideration. The European Journal of Finance, 18, 969-987. https://doi.org/10.1080/1351847X.2011.601643

[8] Harris, R., McInish, T.H., Shoesmith, G.C. and Wood, R.A. (1995) Cointegration, Error Correction, and Price Discovery Informationally Linked Security Markets. Journal of Financial and Quantitative Analysis, 30, 563-579. https://doi.org/10.2307/2331277

[9] Hasbrouck, J. (1995) One Security, Many Markets: Determining the Contributions to Price Discovery. The Journal of Finance, 50, 1175-1199. https://doi.org/10.1111/j.1540-6261.1995.tb04054.x

[10] Garbade, K.D. and Silber, W.L. (1982) Best Execution in Securities Markets: An Application of Signaling and Agency Theory. The Journal of Finance, 37, 493-504. https://doi.org/10.1111/j.1540-6261.1982.tb03570.x

[11] Finnerty, J.E. and Park, H.Y. (1987) Stock Index Futures: Does the Tail Wag the Dog? Financial Analysts Journal, 43, 57-61. https://doi.org/10.2469/faj.v43.n2.57

[12] Ng, N. (1987) Detecting Spot Forecasts in Futures Prices Using Causality Tests. Review of Futures Markets, 6, 250-267.

[13] Kawaller, I.G., Koch, P.D. and Koch, T.W. (1987) The Relationship between the S \& P 500 Index and S \& P 500 Index Futures Prices. The Journal of Finance, 42, 1309-1329.

[14] Harris, L. (1989) S \& P 500 Cash Stock Price Volatilities. Journal of Finance, 44, 1155-1175. https://doi.org/10.1111/j.1540-6261.1989.tb02648.x

[15] Stoll, H.R. and Whaley, R.E. (1990) The Dynamics of Stock Index and Stock Index Futures Returns. Journal of Financial and Quantitative Analysis, 25, 441-468. https://doi.org/10.2307/2331010

[16] Chan, K. (1992) A Further Analysis of the Lead-Lag Relationship between the Cash Market and Stock Index Futures Market. The Review of Financial Studies, 5, 123-152. https://doi.org/10.1093/rfs/5.1.123

[17] Manaster, S. and Rendleman Jr., R.J. (1982) Option Prices as Predictors of Equilibrium Stock Prices. The Journal of Finance, 37, 1043-1057. https://doi.org/10.1111/j.1540-6261.1982.tb03597.x

[18] Bhattacharya, M. (1987) Price Changes of Related Securities: The Case of Call Options and Stocks. Journal of Financial and Quantitative Analysis, 22, 1-15. https://doi.org/10.2307/2330866 
[19] Stephan, J.A. and Whaley, R.E. (1990) Intra-Day Price Change and Trading Volume Relations in the Stock and Stock Option Markets. The Journal of Finance, 45, 191-220. https://doi.org/10.1111/j.1540-6261.1990.tb05087.x

[20] Vijh, A.M. (1990) Liquidity of the CBOE Equity Options. The Journal of Finance, 45, 1157-1179. https://doi.org/10.1111/j.1540-6261.1990.tb02431.x

[21] Damodaran, A. and Lim, J. (1991) The Effects of Option Listing on the Underlying Stocks' Return Processes. Journal of Banking \& Finance, 15, 647-664. https://doi.org/10.1016/0378-4266(91)90090-9

[22] John, K., Koticha, A. and Subrahmanyam, M.G. (1991) The Micro-Structure of Options Markets: Informed Trading, Liquidity, Volatility and Efficiency. New York University Salomon Center, New York.

[23] Easley, D., O’Hara, M. and Srinivas, P.S. (1993) Option Volume and Stock Prices: Evidence on Where Informed Traders Trade. Working Paper, Cornell University.

[24] Thenmozhi, M. and Thomas, S.M. (2007) Price Discovery and Volatility Spillover in Spot and Futures Market: Evidence from India. Indian Journal of Capital Market, 4, 1-28.

[25] Sakthivel, P. and Kamaiah, B. (2010) Price Discovery and Volatility Spillover between Spot and Futures Markets: Evidence from India. IUP Journal of Applied Economics, 9, 81-97.

[26] Srinivasan, P. (2012) Price Discovery and Volatility Spillovers in Indian Spot-Futures Commodity Market. IUP Journal of Behavioral Finance, 9, 70-85.

[27] Gupta, K. and Singh, B. (2006) Price Discovery and Causality in Spot and Futures Markets in India. The ICFAI Journal of Derivatives Markets, 3, 30-41.

[28] Harvey, C.R. and Huang, R.D. (1991) Volatility in the Foreign Currency Futures Market. The Review of Financial Studies, 4, 543-569.

https://doi.org/10.1093/rfs/4.3.543

[29] Han, L.M. and Ozocak, O. (2002) Risk-Return Relationships in Foreign-Currency Futures Following Macroeconomic Announcements. Journal of Futures Markets. Futures, Options, and Other Derivative Products, 22, 729-764. https://doi.org/10.1002/fut.10030

[30] Inagaki, K. (2007) Testing for Volatility Spillover between the British Pound and the Euro. Research in International Business and Finance, 21, 161-174. https://doi.org/10.1016/j.ribaf.2006.03.006

[31] Bubák, V., Kočenda, E. and Žikeš, F. (2011) Volatility Transmission in Emerging European Foreign Exchange Markets. Journal of Banking \& Finance, 35, 2829-2841. https://doi.org/10.1016/j.jbankfin.2011.03.012

[32] Antonakakis, N. (2012) Exchange Return Co-Movements and Volatility Spillovers before and after the Introduction of Euro. Journal of International Financial Markets, Institutions and Money, 22, 1091-1109. https://doi.org/10.1016/j.intfin.2012.05.009

[33] Osler, C.L., Mende, A. and Menkhoff, L. (2011) Price Discovery in Currency Markets. Journal of International Money and Finance, 30, 1696-1718. https://doi.org/10.1016/j.jimonfin.2011.08.004

[34] Égert, B. and Kočenda, E. (2014) The Impact of Macro News and Central Bank Communication on Emerging European Forex Markets. Economic Systems, 38, 73-88. https://doi.org/10.1016/j.ecosys.2013.01.004

[35] Martens, M. and Kofman, P. (1998) The Inefficiency of Reuters Foreign Exchange Quotes. Journal of Banking \& Finance, 22, 347-366. 
https://doi.org/10.1016/S0378-4266(98)00004-1

[36] Tse, Y. (1999) Price Discovery and Volatility Spillovers in the DJIA Index and Futures Markets. Journal of Futures Markets, 19, 911-930.

https://doi.org/10.1002/(SICI)1096-9934(199912)19:8<911::AID-FUT4>3.0.CO;2-Q

[37] Roope, M. and Zurbruegg, R. (2002) The Intra-Day Price Discovery Process between the Singapore Exchange and Taiwan Futures Exchange. Journal of Futures Markets. Futures, Options, and Other Derivative Products, 22, 219-240. https://doi.org/10.1002/fut.2215

[38] Karmakar, M. (2009) Price Discoveries and Volatility Spillovers in S \& P CNX Nifty Future and Its Underlying Index CNX Nifty. Vikalpa, 34, 41-56.

[39] Mahalik, M.K., Acharya, D. and Babu, S. (2009) Price Discovery and Volatility Spillovers in Futures and Spot Commodities Markets: Some Empirical Evidence from India. IGIDR Proceedings, PP062-10.

[40] Dickey, D.A. and Fuller, W.A. (1981) Likelihood Ratio Statistics for Autoregressive Time Series with a Unit Root. Econometrica: Journal of the Econometric Society, 49, 1057-1072. https://doi.org/10.2307/1912517

[41] Johansen, S. (1988) Statistical Analysis of Cointegration Vectors. Journal of Economic Dynamics and Control, 12, 231-254. https://doi.org/10.1016/0165-1889(88)90041-3

[42] Huang, R.D., Cai, J. and Wang, X. (2002) Information-Based Trading in the Treasury Note Interdealer Broker Market. Journal of Financial Intermediation, 11, 269-296. https://doi.org/10.1006/jfin.2002.0338 